Article

\title{
Removal of Ammonia from the Municipal Waste Treatment Effluents using Natural Minerals
}

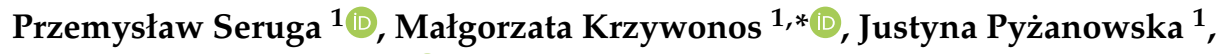 \\ Agnieszka Urbanowska ${ }^{2}$ D , Halina Pawlak-Kruczek ${ }^{3}$ and Łukasz Niedźwiecki ${ }^{3}$ \\ 1 Department of Bioprocess Engineering, Wrocław University of Economics and Business, Komandorska \\ 118/120, 53-345 Wrocław, Poland; przemyslaw.seruga@ue.wroc.pl (P.S.); \\ justyna.pyzanowska@gmail.com (J.P.) \\ 2 Faculty of Environmental Engineering, Chair in Water and Wastewater Treatment Technology, Wroclaw \\ University of Science and Technology, Wyb. Wyspiańskiego 27, 50-370 Wrocław, Poland; \\ agnieszka.urbanowska@pwr.edu.pl \\ 3 Faculty of Mechanical and Power Engineering, Department of Boilers, Combustion and Energy Processes, \\ Wroclaw University of Science and Technology, Wyb. Wyspiańskiego 27, 50-370 Wrocław, Poland; \\ halina.pawlak@pwr.edu.pl (H.P.-K.); lukasz.niedzwiecki@pwr.edu.pl (Ł.N.) \\ * Correspondence: malgorzata.krzywonos@ue.wroc.pl; Tel.: +48-713-680-872
}

Academic Editor: Conchi O. Ania

Received: 12 August 2019; Accepted: 8 October 2019; Published: 9 October 2019

\begin{abstract}
Due to various ecological problems, it is required to remove the ammonia nitrogen from wastewater. Industrial wastewater that was not subjected to any purification was used in this study, while most processes described in the literature were carried out using synthetically prepared solutions. The study investigated the removal of ammonium ions using ion exchange on various commercial minerals, in $3 \mathrm{~h}$ long batch ion-exchange experiments. Furthermore, research on the sodium chloride activation of the selected mineral was conducted. The screening of the mineral with the highest removal potential was conducted taking into account the adsorption capacity (q) and maximal removal efficiency (E), based on the $\mathrm{NH}_{4}{ }^{+}$ions changes determined using the selective electrode and spectrophotometric cuvette tests. The highest adsorption capacity $(\mathrm{q}=4.92 \mathrm{mg} / \mathrm{g})$ of ammonium ions with the maximum removal efficiency (52.3\%) was obtained for bentonite, with a $0-0.05 \mathrm{~mm}$ particle size. After pretreatment with a $1 \mathrm{~mol} / \mathrm{L} \mathrm{NaCl}$ solution, maximum efficiency increments were observed (55.7\%). The Langmuir adsorption isotherm corresponds well with the equilibrium adsorption data ( $R^{2}$ from 0.97 to 0.98 ), while the Freundlich model was found to be mismatched $\left(R^{2}=0.77\right)$. Based on these results it was concluded that natural sorbents may be effectively applied in wastewater treatment. It can be observed that as the size of sorbent particles gets lower, the adsorption capacity, as well as the removal efficiency, gets higher. The bentonite pretreatment with the $\mathrm{NaCl}$ solution did not result in the expected efficiency improvement. The $2 \mathrm{~mol} / \mathrm{L}$ solution affected about $3.5 \%$ of the removal efficiency yield.
\end{abstract}

Keywords: ion exchange; zeolite; bentonite; isotherm; wastewater; adsorption

\section{Introduction}

Municipal, industrial, and agricultural activities generate ammonia nitrogen discharges into environmental resources. The excessive accumulation of ammonium that is discharged into water can cause serious ecological problems, such as: The accelerated eutrophication of lakes and rivers, the depletion of dissolved oxygen, and toxicity in fish and other aquatic animals in the water body [1]. The removal of ammonia from processes or waste effluents is required, due to its toxicity. 
The effluent treatment processes are based on the elimination of pollutants (anaerobic and aerobic biological processes, adsorption, chemical oxidation, or combustion) [2,3] or concentration (flocculation, precipitation, ultrafiltration, nanofiltration, reverse osmosis, and evaporation) $[4,5]$.

The most widely used methods for removing ammonia from wastewater are air stripping [6,7], ion exchange [8,9], breakpoint chlorination [10], and biological nitrification-denitrification [11,12]. The traditional method of removing ammonia from municipal and industrial wastewaters is based on biological treatments. However, it can be easily inhibited by toxic shock, $\mathrm{pH}$ change, low-dissolved oxygen, and low temperature in winter [11,12].

Removal of the nitrogen load through the precipitation of struvite $\left(\mathrm{MgNH}_{4} \mathrm{PO}_{4} \times 6 \mathrm{H}_{2} \mathrm{O}\right)$ is another applicable method for wastewater treatment. However, it is limited by several factors, such as: $\mathrm{pH}$, temperature, as well as magnesium, phosphorus, and calcium content. In the case of a high content of $\mathrm{NH}_{4}{ }^{+}$ions, the addition of $\mathrm{Mg}^{2+}$ or $\mathrm{PO}_{4}{ }^{3-}$ and maintenance of a weakly alkaline environment is required to achieve the crystallization of struvite [13].

Natural zeolites are porous materials, which have a three-dimensional framework structure with cavities. Their physico-chemical properties include high cation exchange capacity, cation selectivity, and high void volume $[14,15]$. Thus, they have many industrial applications, ranging from being used in food supplements or medical devices, to environmental remediation [16], including wastewater treatment. The factors that have an impact on the removal of ammonium from the effluents are mainly $\mathrm{pH}$, temperature, reaction time, particle size, initial concentration of ions, and adsorbent dosage [17].

The ion exchange (IE) by the means of natural minerals, such as zeolites or bentonites, became more competitive and interesting because of its low cost, and its relative simplicity of application and utilization. Furthermore, IE enables the recovery of the ammonium and its reuse for other purposes, e.g., as $\mathrm{N}$-fertilizer [2]. The usage of natural sorbents in $\mathrm{N}$ recovery can be helpful in modification of the natural $\mathrm{N}$ cycle, to avoid further growth of anthropogenic reactive $\mathrm{N}$ environmental impact and its changes [18]. Thus, it is important to foster different wastewater treatment methods other than the biological nitrification-denitrification, which only removes yet does not recover ammonium. Zeolite fully corresponds with this idea, as it is beneficial to soil and crops as a supplementary material to common fertilizers [19], as it increases the nitrification rates of the applied $\mathrm{NH}_{4}{ }^{+}$to soil, and, consequently, the N-uptake in plants [20].

Although natural minerals possess advantages such as good selectivity to $\mathrm{NH}_{4}{ }^{+}$, good availability, and low cost, they have not been widely used on a commercial scale for wastewater treatment, probably because the exchanged minerals require further disposal, or because of the application of the regeneration process [15].

The results, reported in various works, focused on the factors that impact ammonium removal, however, these works were based on the adsorption with particular minerals and synthetic ammonia solutions [14,15], while this study uses the industrial wastewater collected from mechanical-biological treatment (MBT) plants. Furthermore, no purification of the effluent was carried out before the IE trials, and research was performed in situ, directly in the plant. In addition to that, a review of the published literature indicates that there is a significant variation in ion exchange characteristics and structure regarding zeolites from different sources, as well as suspensions found in wastewater, that also hinder the treatment process. Moreover, in general, each study was performed using a single mineral, while in this study a comparison of different sorbents applied to the same effluent was conducted.

The main aim of this study was to examine the possibilities of removing the ammonium ions from the industrial effluents using various commercial minerals. An investigation and comparison of the $\mathrm{NH}_{4}{ }^{+}$ion removal was carried out. Furthermore, the study on the sodium activation of the chosen mineral was conducted. Based on the research, the novel method for wastewater treatment that was originally applied in the MBT plant was determined. 


\section{Results and Discussion}

\subsection{Screening of the Commercial Minerals (Non-Modified)}

The screening was conducted in several stages. In the first stage, $3 \mathrm{~h}$-long batch experiments were carried out to remove ammonium ions from the effluents using three natural sorbents, with a particle size of $0.5-1 \mathrm{~mm}$. Their commercial names were: Zeocem Eco, Biozeo R01, and Zeolite Subio.

The content of ammonium ions (expressed in \%) during the sorption processes is shown in Figure 1. The highest ammonium ions removal efficiency was noted for Zeolite Subio (40.4\%), followed by an $18.0 \%$ reduction noted for Biozeo R01. It should be noted that in the initial phase, the increase in the concentration of ammonium ions was observed. The increment might have occurred as a result of stirring, and the change in $\mathrm{pH}$, resulting from the addition of sorbent. (Figure 1).

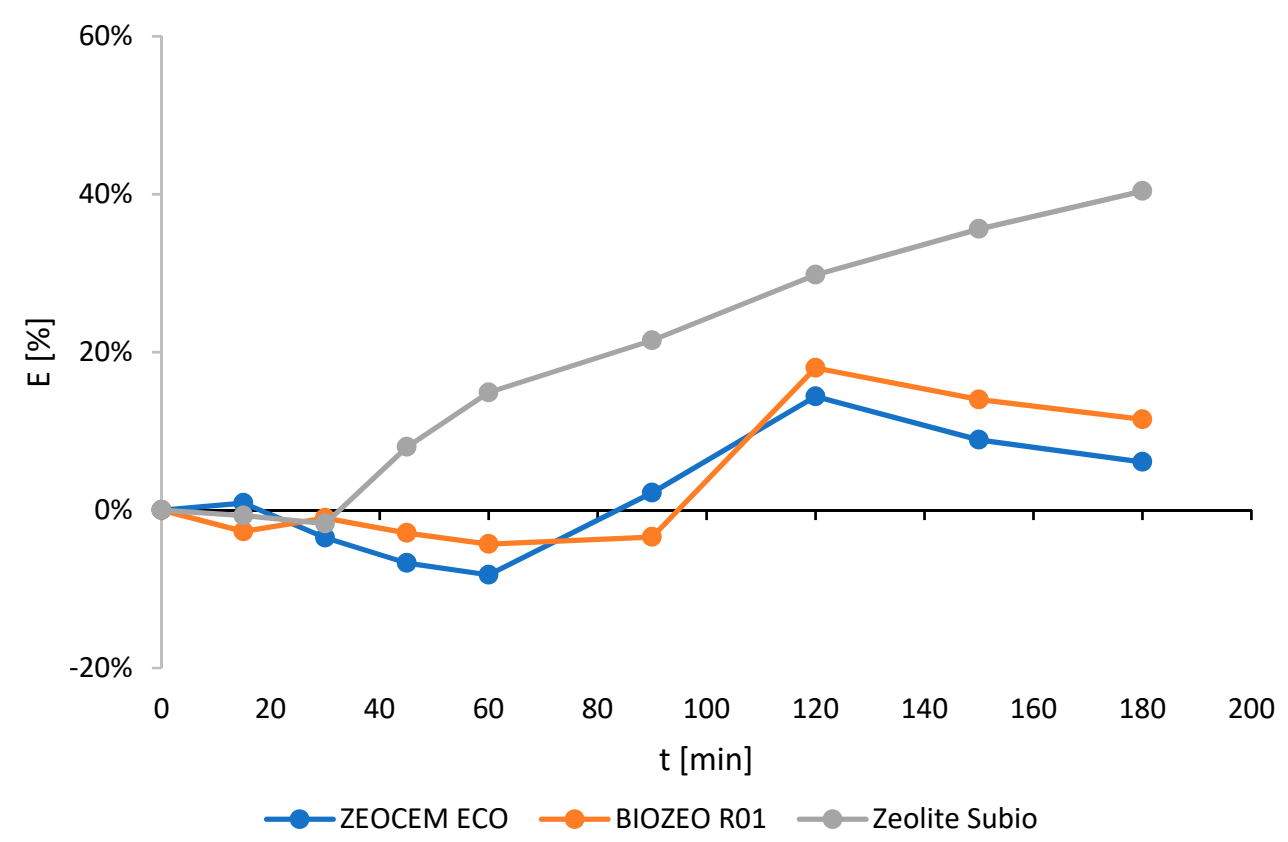

Figure 1. The ammonium ions removal efficiency (E) for Zeocem Eco, Biozeo R01, and Zeolite Subio.

In regards to zeolite, for which the highest ammonium ions removal efficiency was achieved (Zeolite Subio), a series of experiments was repeated for three different granulometric fractions: I: 0.5-1.0 mm; II: $0.2-0.5 \mathrm{~mm}$; and III: $0.0-0.2 \mathrm{~mm}$. When using fraction II, a similar level of ammonium removal was observed, amounting to approximately $40.5 \%$ (Figures 1 and 2). For the smallest sorbent grains (fraction III) the efficiency of $34 \%$ was noted (Figure 2).

The batch experiments were also repeated for non-modified sorbents with the particle size of $0-0.05 \mathrm{~mm}$ (Figure 3). The highest removal efficiency of ammonium ions from effluents at $52.3 \%$ was observed for the bentonite I sample (by $85 \%$ of the montmorillonite content). The lowest efficiency was achieved when Terra Bent Agro (40.3\%) was used. For the other two sorbents, the ammonium content decreased from 43.8 to $44.9 \%$ (Figure 3 ). 


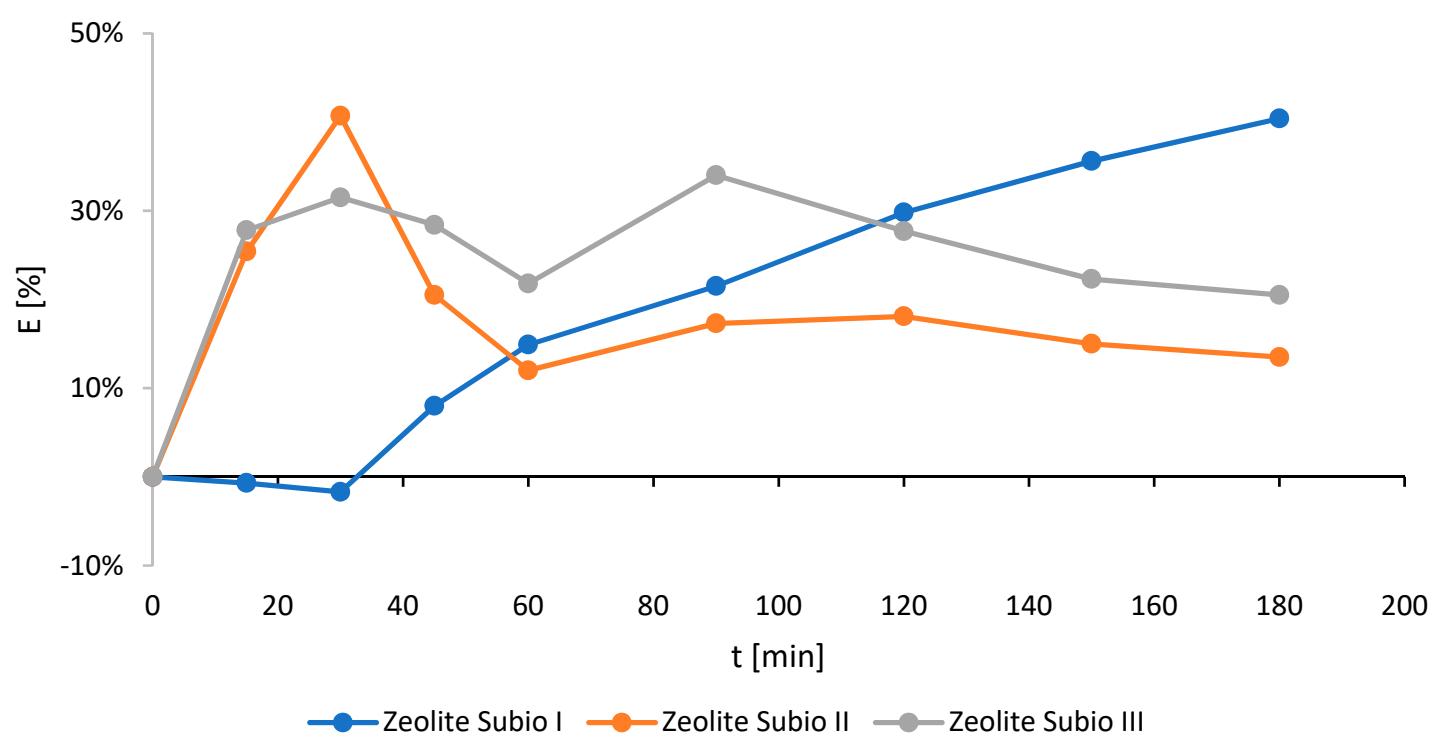

Figure 2. Effect of Zeolite Subio's particle size on the ammonium ions removal efficiency (E) (particle size I: $0.5-1.0 \mathrm{~mm}$; II: $0.2-0.5 \mathrm{~mm}$; and III: $0.0-0.2 \mathrm{~mm}$ ).

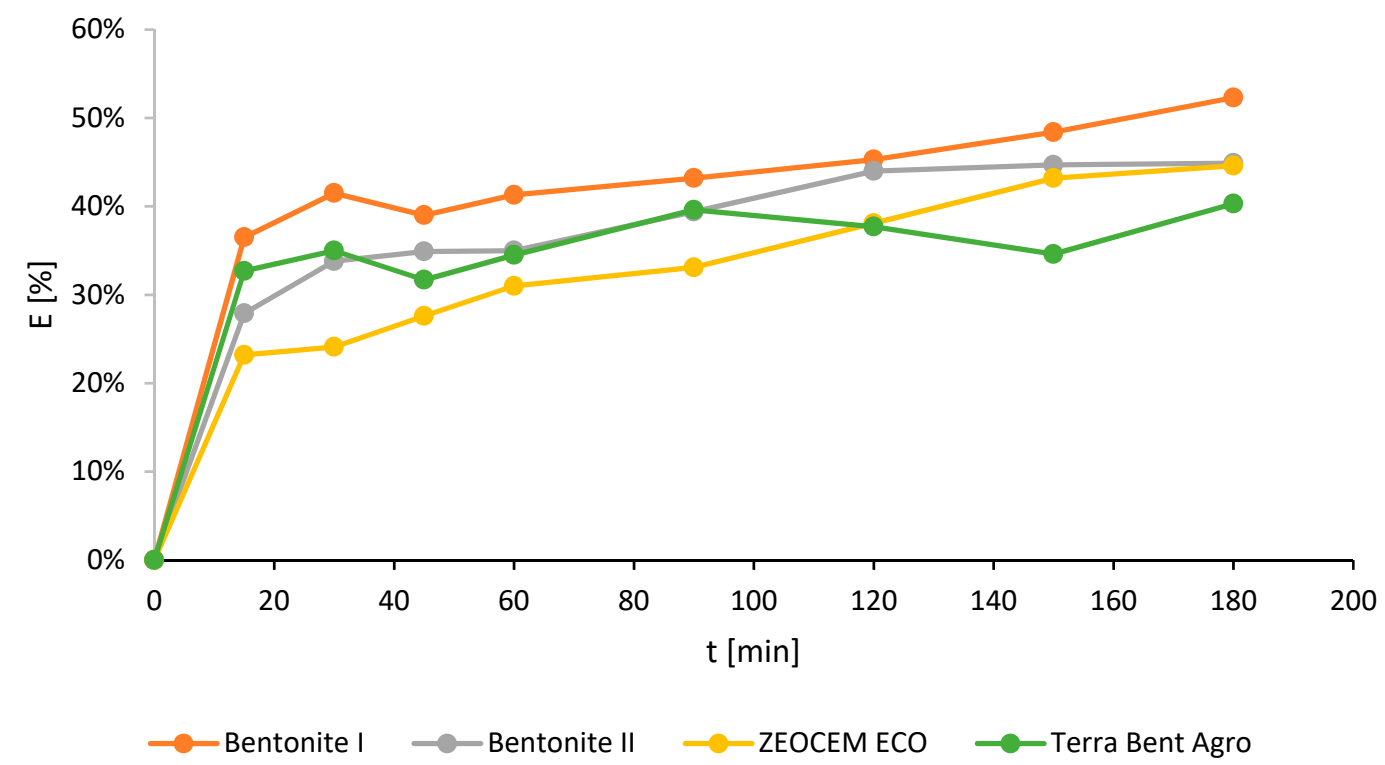

Figure 3. The ammonium ions removal efficiency (E) for Bentonite I and II, Zeocem Eco, and Terra Bent Agro.

Alshameri et al. [17] determined the amount of time that is required to remove ammonium from synthetic solutions $\left(\mathrm{NH}_{4} \mathrm{Cl}\right.$ diluted in distilled water with an initial concentration of ammonium ions $80 \mathrm{mg} / \mathrm{L}, \mathrm{pH}=7$ ) using natural zeolite. The results confirmed that, due to the prolongation of the process, the ammonium ions removal efficiency increased. The authors obtained $40 \%$ removal within the first $10 \mathrm{~min}$, and 78\% after $300 \mathrm{~min}$ [17]. Similar research was carried out using natural zeolite from Yemen [14]. The removal efficiency of $\mathrm{NH}_{4}{ }^{+}$ions at 39\% was reported within $10 \mathrm{~min}$, and after $2 \mathrm{~h}$ it reached $80 \%$.

The noted $\mathrm{NH}_{4}{ }^{+}$adsorption capacity and the maximum ammonium removal efficiencies for the minerals analyzed in this research were illustrated using data presented in Table 1. 
Table 1. Effect of using different sorbents on the $\mathrm{NH}_{4}{ }^{+}$adsorption capacity (q) and maximum removal efficiency (E) obtained in performed research.

\begin{tabular}{ccccc}
\hline $\begin{array}{c}\text { Mineral } \\
\text { Commercial Name }\end{array}$ & $\begin{array}{c}\text { Particular Size } \\
{[\mathbf{m m}]}\end{array}$ & $\begin{array}{c}\text { Adsorption } \\
\text { Capacity (q) } \\
{\left[\mathbf{m g N / g _ { \mathbf { z } } ]}\right.}\end{array}$ & $\begin{array}{c}\text { Maximal Removal } \\
\text { Efficiency (E) } \\
{[\%]}\end{array}$ & $\begin{array}{c}\text { Needed Contact } \\
\text { Time to Achieve } \\
\text { Maximum E [min] }\end{array}$ \\
\hline Zeocem Eco & $0.5-1$ & 0.39 & 14.4 & 120 \\
Biozeo R.01 & $0.5-1$ & 0.77 & 18.0 & 120 \\
Zeolite Subio I & $0.5-1$ & 3.05 & 40.4 & 180 \\
Zeolite Subio II & $0.2-0.5$ & 0.99 & 40.7 & 30 \\
Zeolite Subio III & $0-0.2$ & 1.43 & 34.0 & 90 \\
Bentonite I & $0-0.05$ & 4.92 & 52.3 & 180 \\
Bentonite II & $0-0.05$ & 4.22 & 44.9 & 180 \\
Zeocem Eco & $0-0.05$ & 4.2 & 44.6 & 180 \\
Terra Bent Agro & $0-0.05$ & 3.79 & 40.3 & 180 \\
\hline
\end{tabular}

The highest adsorption capacity was measured when the finest granulation sorbents were used. The highest ammonium ions removal efficiencies were also noted for them. The removal efficiency for most of the examined minerals reached $40-45 \%$ within $180 \mathrm{~min}$ (Table 1 ).

The influence of the duration of the process on the ammonium ions removal efficiency was also examined [15]. The authors used natural zeolite and synthetic sewage, obtained by dilution in distilled water with $\mathrm{NH}_{4} \mathrm{Cl},\left(\mathrm{NH}_{4}\right)_{2} \mathrm{HPO}_{4}, \mathrm{KCl}, \mathrm{MgCl}_{2}, \mathrm{NaCl}, \mathrm{CaCl}_{2}, \mathrm{Na}_{2} \mathrm{SO}_{4}$, and $\mathrm{NaNO}_{3}$. The initial concentration of $\mathrm{NH}_{4}{ }^{+}$ions was established at $322 \mathrm{mg} / \mathrm{L}$. The authors stated that along with the prolonged contact between the sewage and the sorbent, the ammonium removal efficiency increased. After $10 \mathrm{~min}, 42 \%$ removal efficiency from synthetic sewage was obtained. However, lengthening the process did not result in further wastewater treatment [15]. The explanation of this phenomenon may be that the most available adsorption sites of zeolite were used, which led to rapid diffusion and equilibrium. When the outer surface is saturated, ion exchange occurs at the pores of the sorbent and its internal surface [10,12]. This may confirm that the ion exchange was the main mechanism of ammonium ions removal, according to the equation (1), proposed by Alshameri et al. [17]:

$$
\text { Zeolite- } \mathrm{Na}^{+}+\mathrm{NH}_{4}{ }^{+}=\text {Zeolite- } \mathrm{NH}_{4}{ }^{+}+\mathrm{Na}^{+}
$$

During the ion exchange, concentrations of sodium and ammonium ions decrease and increase, this results in the reduction of the driving force of $\mathrm{NH}_{4}{ }^{+}$adsorption on zeolites, which may also explain the mechanism that takes place in this method of wastewater treatment [15]. Moreover, the research that has been carried out can confirm the presented statements. The suspensions which occurred in the effluents might have saturated the outer surface of the minerals, and even disturbed the sorption process at the pores of the minerals, which led to a lower efficiency of the effluent treatment.

The treatment of a $1 \mathrm{~g} / \mathrm{L}$ solution of ammonium chloride using clinoptilolite (of different particle sizes: 20, 30, and $40 \mathrm{~mm}$ ) was performed by Rahmani et al. [9]. An inverse dependence of the efficiency of the process on the grain size was observed. Using clinoptilolite with a smaller granulation resulted in an improved absorption [9]. Similar findings might be made based on the performed research. The observed ammonium ions removal efficiencies were, in general, at higher levels for minerals with a smaller particle size (Table 1).

\subsection{The Studies on Activated Sorbent}

Taking into consideration the highest adsorption capacity and the maximum removal efficiency obtained in the performed research (Table 1), Bentonite I was chosen to be investigated further, and activated using sodium chloride.

The chemical oxygen demand removal would be an additional benefit for the MBT in the context of internal wastewater treatment. For this reason it was also determined during studies on activated 
minerals. The highest chemical oxygen demand (COD) removal was obtained for samples activated with a $2.0 \mathrm{~mol} / \mathrm{L} \mathrm{NaCl}$ solution (21.9\%). Due to the other activated samples, the obtained COD removal varied from 10.4 to $11.0 \%$, and was similar to the COD removal (11.3\%) observed for natural bentonite. The low COD removal may have been influenced by the composition of the effluent.

Changes in the percentage of the ammonium ions content during the sorption processes were presented in Figure 4. The highest ammonium ions removal efficiency was noted for bentonite activated with a $1 \mathrm{~mol} / \mathrm{L} \mathrm{NaCl}$ solution at $55.9 \%$, after a $55.7 \%$ reduction for a $0.5 \mathrm{~mol} / \mathrm{L}$ activating solution. Due to the use of natural bentonite, an efficiency level that was over $50 \%$ was noticed again (Figure 4 ). Moreover, a $1 \mathrm{~mol} / \mathrm{L}$ concentration of $\mathrm{NaCl}$ was found to be the most effective in pretreatment, resulting in adsorption of $\mathrm{NH}_{4}{ }^{+}$ions on Yemeni natural zeolite [14], and Hulaodu natural zeolite [17].

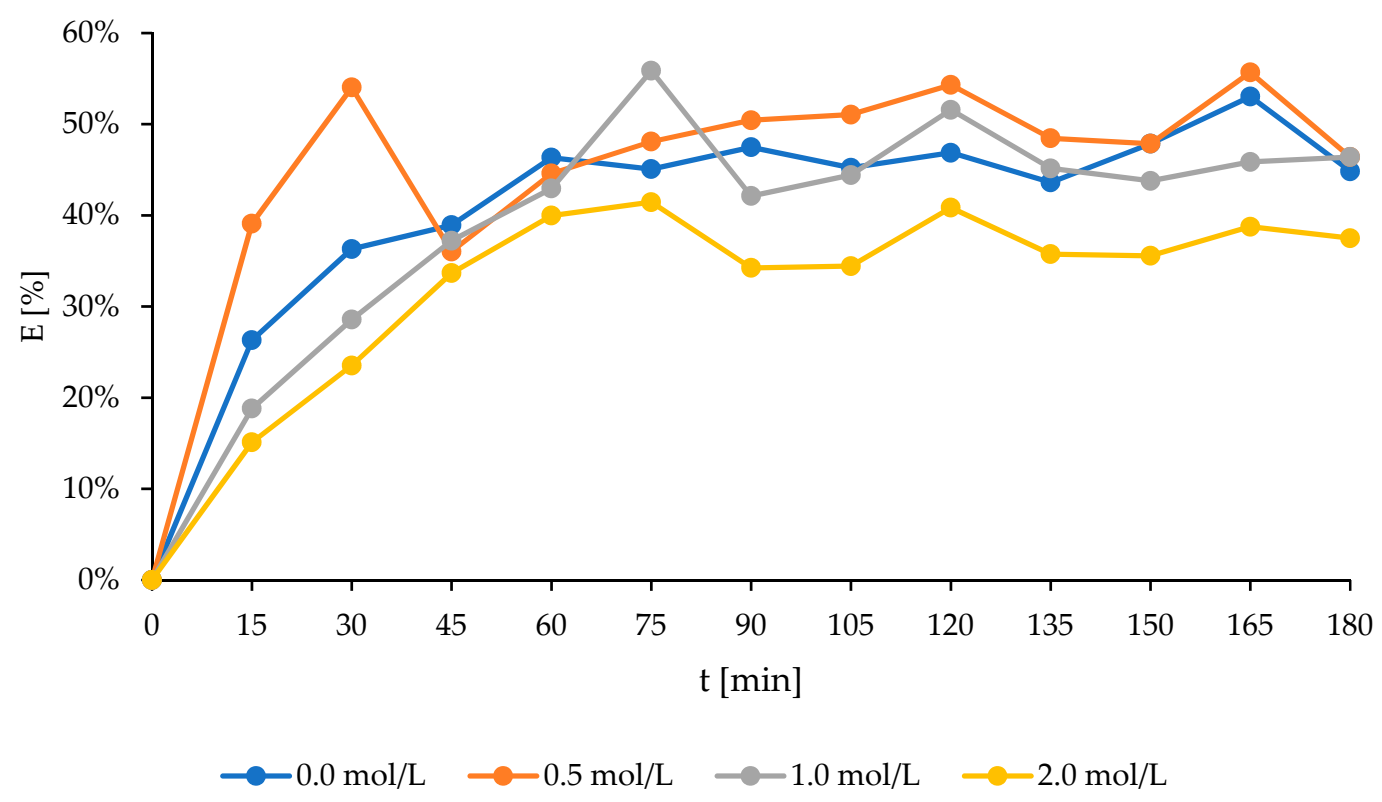

Figure 4. The effect of using different $\mathrm{NaCl}$ solutions for the activation of Bentonite I on ammonium ions removal efficiency $(\mathrm{E})$.

It is essential to use an ion-exchange isotherm to describe the equilibrium relationship between the amount of ion exchanged by a mineral and its equilibrium concentration in the solution [21], which could be used to optimize the use of a mineral as adsorbent [22].

The amounts of adsorbed ammonium ions in time using the Freundlich model were corresponded to the experimental values (Figure 5), which indicate the adjustment of data obtained during the experiment to this model. The Freundlich isotherm is applicable to adsorption processes that occur on heterogonous surfaces [23]. This isotherm gives an expression which defines the surface heterogeneity and the exponential distribution of active sites and their energies [24]. Low values of the adsorption process constant $\left(\mathrm{k}_{1}\right)$ were observed, regardless of the $\mathrm{NaCl}$ solution used for sorbent activation: 0.013 , $0.030,0.021$, and $0.013 \mathrm{~min}^{-1}$ for natural bentonite and pretreated bentonite with increasing $\mathrm{NaCl}$ concentrations, respectively. Its decrease was observed followed by the increment in the saturation of bentonite with $\mathrm{NaCl}$. A similar pattern was noticed for the adsorption capacity $\left(\mathrm{q}_{\mathrm{e}}\right)$. 


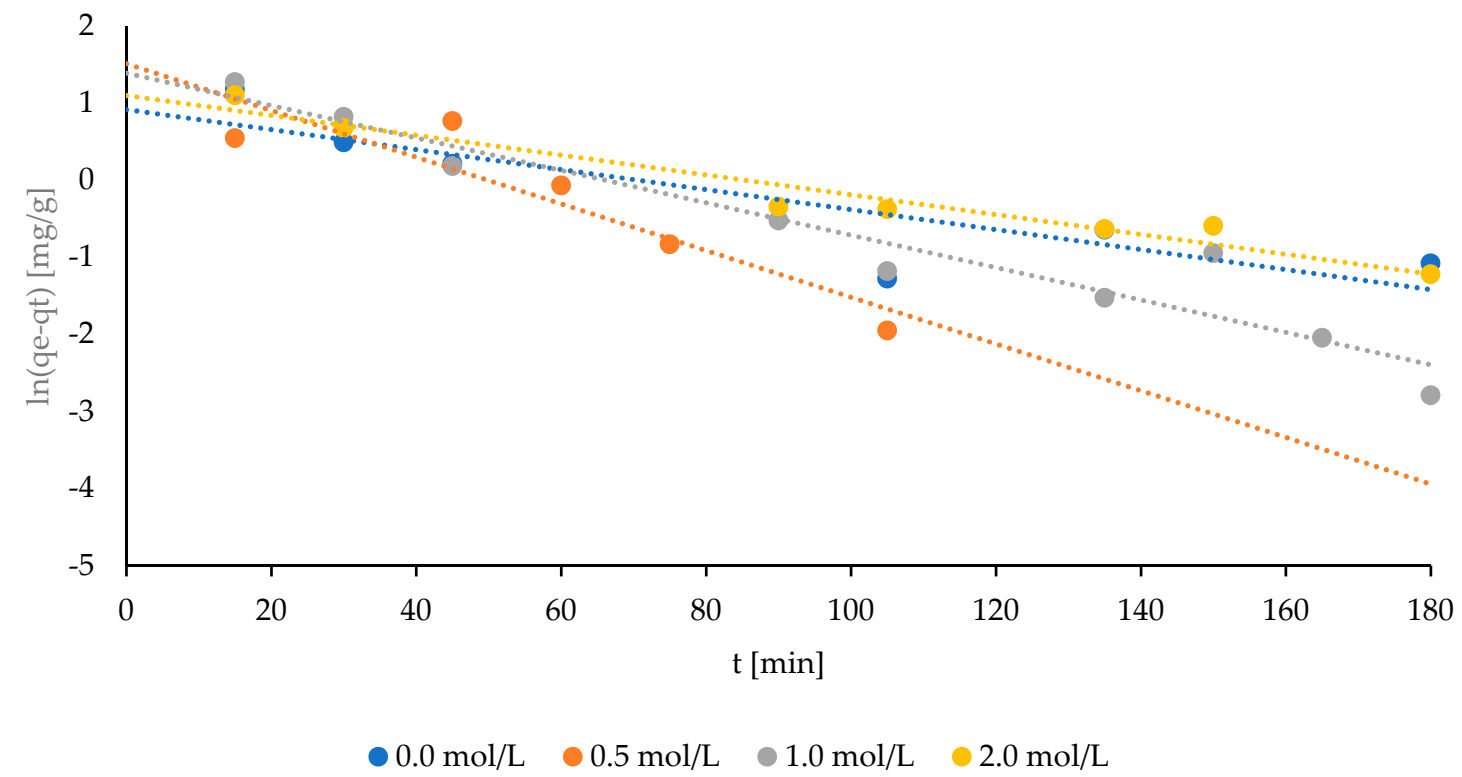

Figure 5. The adaptation of experimental data of ammonium adsorption obtained for the natural and modified Bentonite I-Freundlich isotherms.

Kinetic parameters for the ammonium ion exchange using the pseudo-second-order model were shown in Table 2. However, the low values of the correlation coefficient $R^{2}$ can be noticed (Table 2). The highest $\mathrm{R}^{2}$ was observed for the bentonite activated by a $2 \mathrm{~mol} / \mathrm{L}$ sodium chloride solution (0.947), and the lowest for the natural bentonite (0.772) (Table 2). It can be found that the obtained data does not correspond to the Freundlich model, especially for the case of the natural bentonite, and for the bentonite activated with $\mathrm{NaCl}$ in relatively low concentrations. The determination coefficient $\left(\mathrm{R}^{2}\right)$ of 0.772 (which means that $77.2 \%$ of the total variation is explained by the model) cannot suggest a satisfactory representation of the process model, or a strong correlation between the experimental and predicted values $[25,26]$.

Table 2. The kinetic parameters for ammonium ion exchange using the Freundlich model $(0.5 \mathrm{M}, 1 \mathrm{M}$, and $2 \mathrm{M}$ indicate $\mathrm{NaCl}$ concentrations of $0.5,1.0$, and $2.0 \mathrm{~mol} / \mathrm{L}$ respectively).

\begin{tabular}{cccc}
\hline Mineral & $\mathbf{k}_{\mathbf{1}}\left[\mathbf{m i n}^{-\mathbf{1}}\right]$ & $\mathbf{q}_{\mathbf{e}}\left[\mathbf{m g N} / \mathbf{g}_{\mathbf{z}}\right]$ & $\mathbf{R}^{\mathbf{2}}$ \\
\hline Natural bentonite I & 0.013 & 7.164 & 0.772 \\
0.5 M activated bentonite I & 0.030 & 7.285 & 0.840 \\
1 M activated bentonite I & 0.021 & 5.828 & 0.924 \\
2 M activated bentonite I & 0.013 & 4.748 & 0.947 \\
\hline
\end{tabular}

It can be stated that the ion-exchange kinetics of $\mathrm{NH}_{4}{ }^{+}$on zeolite were regulated by both surface and intraparticle diffusion processes (Table 1, Table 2, Table 3, and Figure 4). The ammonium exchange process was preceded by surface sorption and intraparticle diffusion. It has been suggested that the first one can be attributed to the instantaneous occupation of the most available surface sites on the zeolites' particles by the exchanging ammonium ions. The surface of zeolites might be negatively charged thus, making the rate of ion exchange of the $\mathrm{NH}_{4}{ }^{+}$very fast. The second region is due to the gradual ion exchange of the $\mathrm{NH}_{4}{ }^{+}$into zeolite particles, by intraparticle diffusion through the pores. The resistance to the external mass transfer increases as the intercept increases $[14,17]$. 
Table 3. The kinetic parameters for ammonium ion exchange using the Langmuir model $(0.5 \mathrm{M}, 1 \mathrm{M}$, and $2 \mathrm{M}$ indicate $\mathrm{NaCl}$ concentrations of $0.5,1.0$, and $2.0 \mathrm{~mol} / \mathrm{L}$, respectively).

\begin{tabular}{ccccc}
\hline Mineral & $\mathbf{k}_{\mathbf{2}}$ [g/mg·min] & $\mathbf{q}_{\mathbf{e}}\left[\mathbf{m g N} / \mathbf{g}_{\mathbf{z}}\right]$ & $\mathbf{h}[\mathbf{m g} / \mathbf{g} \cdot \mathbf{m i n}]$ & $\mathbf{R}^{\mathbf{2}}$ \\
\hline Natural Bentonite I & 0.013 & 7.164 & 6.657 & 0.979 \\
0.5 M activated Bentonite I & 0.134 & 7.285 & 7.127 & 0.972 \\
1 M activated Bentonite I & 0.156 & 5.828 & 5.298 & 0.966 \\
2 M activated Bentonite I & 0.205 & 4.748 & 4.626 & 0.969 \\
\hline
\end{tabular}

A better correlation between the experimental and predicted values was obtained when the Langmuir model was applied (Figure 6).

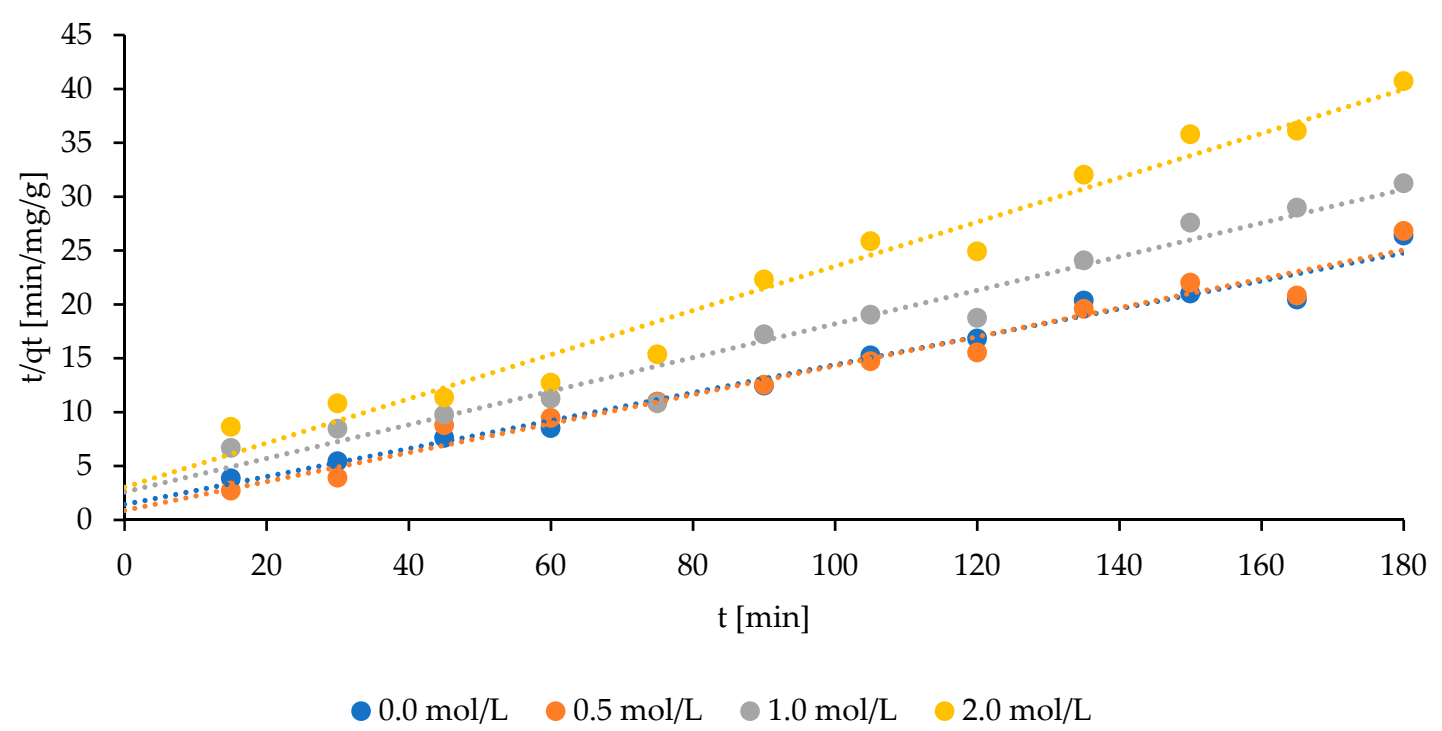

Figure 6. Adaptation of the experimental data of ammonium adsorption obtained for natural and modified Bentonite I-Langmuir isotherm.

This statement can be confirmed by the high correlation coefficient, which was at the level of $0.979,0.972,0.966$, and 0.969 for natural bentonite, and was activated using the increasing $\mathrm{NaCl}$ concentrations, respectively (Table 3).

The decrease in the amount of adsorbed ammonium ions is followed by the increment in $\mathrm{NaCl}$ bentonite saturation, whereas, the speed ratio $\mathrm{k}_{2}$, corresponding with the adsorption, increased with the increment in the saturation of the bentonite with a solution of $\mathrm{NaCl}$. Furthermore, the value of the coefficient $h$ (corresponding to the initial adsorption rate) decreased along with the bentonite saturation increment (Table 3). As it was observed, at the beginning of the runs, an increase in the concentration of ammonium ions caused an increase in the value of the coefficient $h$ (Figure 6, Table 3).

When the Freundlich isotherm was used, the obtained data were not consistent with the data obtained during the experiment (Table 2). The measured kinetic parameters of the adsorption process reached low values, however, it can be observed that the increase in the saturation of bentonite with the $\mathrm{NaCl}$ solution had a negative impact on the coefficient $\mathrm{k}_{1}$ (Table 2). Based on the noticed correlation coefficient $\left(\mathrm{R}^{2}\right)$, the incompatibility of the Freundlich model can be assumed.

The obtained data were consistent with the experimental data when using the Langmuir isotherm, as evidenced by the correlation coefficient $\mathrm{R}^{2}$, exceeding 0.966 (Table 3). With the increase in the saturation of bentonite with the $\mathrm{NaCl}$ solution, the amount of adsorbed $\mathrm{NH}_{4}{ }^{+}$ions decreased. The Langmuir isotherm accounts for the surface coverage by balancing the relative rates of adsorption and desorption (dynamic equilibrium). Adsorption is proportional to the fraction of the surface of the adsorbent that is open, while desorption is proportional to the fraction of the adsorbent surface that is covered [27]. 
The $\mathrm{k}_{2}$ factor increased along with the increasing saturation of bentonite. The adsorption of leachate pollutants with ammonium ions was consistent with the Langmuir model. Vázquez et al. [28] also fitted the Langmuir model, and achieved the highest amount of removed ammonium ions $(38.12 \mathrm{mg} / \mathrm{g})$ using granular activated carbon. Also, Alshameri et al. [14] obtained much higher $\mathrm{R}^{2}$ values (0.997) for the Langmuir model, compared to the Freundlich model (0.736) for the ammonium removal by natural zeolite. However, Huang et al. [15] noticed that in the course of removing ammonium from swine wastewater using zeolite, similar $\mathrm{R}^{2}$ levels were obtained (Langmuir and Freundlich models: 0.997 and 0.985 , respectively). It can be assumed that at least two mentioned models should be investigated and compared to verify the correlation between the experimental and predicted values.

\section{Materials and Methods}

\subsection{The Commercial Minerals}

The minerals used in the present study belong to the silicate family with commercial names: Zeocem Eco provided by Zeocem a.s., Bystré, Slovakia with particle sizes of 0-0.05 mm and 0.5-1 mm, Biozeo R01 from BioDrain Ltd., Rzeszów, Poland with a 0.5-1.0 mm fraction, Zeolite Subio provided by Subio Eko Polska Ltd., Krzyżanowice, Poland with a granulation of $0-0.2 \mathrm{~mm}, 0.2-0.5 \mathrm{~mm}$, and 0.5-1.0 mm, Bentonite I and II provided by Certech Ltd., Niedomice, Poland with a grain size of 0-0.05 mm, and Terra Bent Agro provided by Celpap Ltd., Wieliczka, Poland, with a granulation of 0-0.05 mm.). The mineral and chemical composition of the used minerals, based on the product data sheets, are presented in Table 4.

Table 4. The mineral and chemical composition of used sorbents.

\begin{tabular}{ccccccc}
\hline $\begin{array}{c}\text { Mineral and Chemical } \\
\text { Composition [\%] }\end{array}$ & Zeocem Eco & $\begin{array}{c}\text { Zeolite } \\
\text { Subio }\end{array}$ & Bentonite I & Bentonite II & $\begin{array}{c}\text { Terra Bent } \\
\text { Agro }\end{array}$ & Biozeo R01 \\
\hline Clinoptilolite & 84 & 84 & & & & 60 \\
Cristobalite & 8 & 8 & & & & \\
Clayish mica & 4 & 4 & & & & \\
Plagioclase & $3-4$ & $3-4$ & & & & \\
Edisonite & $0.1-0.3$ & $0.1-0.3$ & & & & \\
Montmorillonite & & & 85 & 65 & $60-80$ & 70.6 \\
$\mathrm{SiO}_{2}$ & $65-71.3$ & $65-71.3$ & $70-80$ & $60-65$ & $11-20$ & 12.32 \\
$\mathrm{Al}_{2} \mathrm{O}_{3}$ & $11.5-13.1$ & $11.5-13.1$ & $13-17$ & $15-20$ & $\mathrm{ND}$ & 1.48 \\
$\mathrm{Fe}_{2} \mathrm{O}_{3}$ & $0.7-1.9$ & $0.7-1.9$ & $1-2$ & $5-7$ & $1.5-5.2$ & 3.42 \\
$\mathrm{CaO}$ & $2.7-5.2$ & $2.7-5.2$ & $0.5-1.5$ & $2-4$ & $\mathrm{ND}$ & 0.71 \\
$\mathrm{TiO}_{2}$ & $0.1-0.3$ & $0.1-0.3$ & $0.05-0.15$ & $0.5-1.0$ & $\mathrm{ND}$ & 0.96 \\
$\mathrm{MgO}_{\mathrm{MnO}}$ & $0.6-1.2$ & $0.6-1.2$ & $0.8-1.8$ & $1-2$ & $\mathrm{ND}$ & 0.02 \\
$\mathrm{~K}_{2} \mathrm{O}$ & $\mathrm{ND}$ & $\mathrm{ND}$ & 0.05 & $<0.05$ & $0.5-3.4$ & 2.83 \\
$\mathrm{Na}_{2} \mathrm{O}$ & $2.2-3.4$ & $2.2-3.4$ & $0.5-2.0$ & $0.5-1.0$ & $\mathrm{ND}$ & 0.68 \\
$\mathrm{P}_{2} \mathrm{O}_{5}$ & $0.2-1.3$ & $0.2-1.3$ & $<0.01$ & $<0.01$ & $\mathrm{ND}$ & $\mathrm{ND}$ \\
$\mathrm{ZrO}_{2}$ & $\mathrm{ND}$ & $\mathrm{ND}$ & $<0,01$ & $<0,1$ & $\mathrm{ND}$ & $\mathrm{ND}$ \\
$\mathrm{Cr}_{2} \mathrm{O}_{3}$ & $\mathrm{ND}$ & $\mathrm{ND}$ & $<0.01$ & $<0.01$ & $\mathrm{ND}$ & $\mathrm{ND}$ \\
$\mathrm{SO}_{3}$ & $\mathrm{ND}$ & $\mathrm{ND}$ & $<0.01$ & $<0.02$ & $\mathrm{ND}$ & $\mathrm{ND}$ \\
$\mathrm{Si}_{3} \mathrm{Al}$. & $\mathrm{ND}$ & $\mathrm{ND}$ & $<0.01$ & $<0.01$ & $\mathrm{ND}$ & ND \\
\hline
\end{tabular}

Before each run, the minerals were dried in an oven at $100{ }^{\circ} \mathrm{C}$ for $1 \mathrm{~h}$.

\subsection{The Industrial Wastewater}

The industrial wastewater used in this study consisted of mixed effluents from both biological treatment processes (anaerobic digestion and oxygen stabilization) of the organic fraction of municipal solid waste, that were performed in the mechanical-biological treatment (MBT) plant (ZGO Gać), and were collected in a $650 \mathrm{~m}^{3}$ tank and used in the research. Its characteristics can be found in Table 5 . All of the analyses have been performed using APHA [29]. 
Table 5. The industrial wastewater characterization.

\begin{tabular}{cc}
\hline Parameter & Value \\
\hline pH [-] & $7.8 \pm 0.3$ \\
Chemical Oxygen Demand (COD) [g/L] & $18.7 \pm 1.3$ \\
Biological Oxygen Demand (BOD) [g/L] & $6.0 \pm 0.5$ \\
Ammonium nitrogen [g/L] & $0.8 \pm 0.2$ \\
Total nitrogen [g/L] & $1.1 \pm 0.3$ \\
Total Organic Carbon (TOC) [g/L] & $3.1 \pm 0.2$ \\
Total suspended solids (TSS) [g/L] & $0.6 \pm 0.2$ \\
$\mathrm{Cl}^{-}[\mathrm{g} / \mathrm{L}]$ & $1.3 \pm 0.2$ \\
\hline
\end{tabular}

\subsection{Ammonium ion Exchange}

Batch ion-exchange experiments were carried out using flasks $(250 \mathrm{~mL})$ in a shaker and shaken at $120 \mathrm{rpm}$ at room temperature in the course of $3 \mathrm{~h}$ using the mineral/liquid ratio of $10 \mathrm{~g} / 100 \mathrm{~mL}$. The $\mathrm{pH}$ value of the effluents was not corrected. The suspended solids were not removed. Every $15 \mathrm{~m}$ the electrode was introduced to measure the content of the ammonium ions.

The screening of minerals with a particle size of $0.5-1.0 \mathrm{~mm}$ was conducted (Zeocem Eco, Biozeo R01, Zeolite Subio) in the first stage of the ammonium ion-exchange research. For the mineral with the highest removal efficiency the experiment was repeated using its different particle sizes (Zeolite Subio). Furthermore, the 3rd trial was performed using sorbent with the smallest granulation (Bentonite I and II, Zeocem Eco, and Terra Bent Agro). Among all of them, the sorbent with the highest ions removal efficiency was chosen for the activation (Bentonite I).

\subsection{The Sorbent Activation}

The activation process was carried out by mixing natural sorbent (Bentonite I) with an aqueous solution of sodium chloride (POCh, Gliwice, Poland). To examine the effect of various sodium concentrations, different $\mathrm{NaCl}$ concentrations were used $(0.5,1.0$, and $2.0 \mathrm{~mol} / \mathrm{L})$. The suspension of $25 \mathrm{~g}$ samples of bentonite and a $250 \mathrm{~mL}$ sodium chloride solution were stirred in the flasks $(500 \mathrm{~mL})$, and kept in water batch $\left(80^{\circ} \mathrm{C}\right)$ for $1 \mathrm{~h}$. Subsequently, the suspension was filtered and washed with distilled water. Afterwards, the wet material was dried at $100^{\circ} \mathrm{C}$ for $24 \mathrm{~h}$.

\subsection{Analytical Methods}

The $\mathrm{NH}_{4}{ }^{+}$adsorption capacity (q) and removal efficiency (E) of mineral were calculated using the equations:

$$
\mathrm{q}=\left(\mathrm{C}_{0}-\mathrm{C}_{\mathrm{k}}\right) \times(\mathrm{V} / \mathrm{m})
$$

and

$$
\mathrm{E}=\left[\left(\mathrm{C}_{0}-\mathrm{C}_{\mathrm{e}}\right) / \mathrm{C}_{0}\right] \times 100 \%
$$

respectively, where: $\mathrm{q}$ (adsorption capacity at time $\mathrm{t}$ ) is the total amount of adsorbed $\mathrm{NH}_{4}{ }^{+}$ions per unit of weight of mineral at time $t\left(\mathrm{mgN} / \mathrm{g}_{\mathrm{z}}\right) ; \mathrm{C}_{0}, \mathrm{C}_{\mathrm{t}}, \mathrm{C}_{\mathrm{e}}$ are the initial, time $\mathrm{t}$, and equilibrium concentrations of $\mathrm{NH}_{4}{ }^{+}$in solution ( $\mathrm{mg} \mathrm{N} / \mathrm{L}$ ); $\mathrm{V}$ is the initial volume of treated effluent $(\mathrm{L}) ; \mathrm{m}$ is the adsorbent mass $(\mathrm{g})$.

The content of ammonium ions in the wastewater was determined using the ammonium ion-selective electrode (DETEKTOR, Raszyn, Poland) with the silver-chloride reference electrode (DETEKTOR, Raszyn, Poland) and the ionometer (ELMETRON CPI-505, Zabrze, Poland). To control the values obtained by means of using the ammonium ion-selective electrode, the spectrophotometric Hach-Lange cuvette tests (LCK 302) (HACH LANGE Ltd., Wrocław, Poland) [30] have been used, and the initial and final concentration has been measured in the course of the experiments.

The chemical oxygen demand (COD) was determined spectrophotometrically using the HACH-Lange cuvette tests (LCK 514) (HACH LANGE Ltd., Wrocław, Poland) [30] at the beginning 
and end of each experiment, when the sorbent activation with $\mathrm{NaCl}$ has been studied to verify the possibility of COD removal.

\subsection{Ammonium Ion-Exchange Isotherms}

Information pertaining to adsorption equilibrium is the most important information that is required for the proper understanding of an adsorption process [31]. The profile obtained from the study of ammonium removal using mineral sorbent was used to obtain adsorption isotherms by using well-known equations of the Langmuir and Freundlich models [15,31].

\section{Conclusions}

The present research examined various types of natural sorbents, with different granulations, determining the efficiency of ammonium ions removal from the waste treatment effluents and the impact of the processing time. The highest adsorption capacity $(4.92 \mathrm{mg} / \mathrm{g})$ with the maximal removal efficiency (52.3\%) was obtained for Bentonite I, with the particle size of $0-0.05 \mathrm{~mm}$. Generally, it was found that the lower the mineral size, the higher the adsorption capacity as well as removal efficiency.

The chosen bentonite sample was pretreated with various $\mathrm{NaCl}$ solutions $(0.5,1.0$, and $2.0 \mathrm{~mol} / \mathrm{L})$. The activated mineral showed higher removal efficiency compared to natural bentonite. Maximum efficiency $(55.7 \%)$ was measured for bentonite I pretreated with the $1 \mathrm{~mol} / \mathrm{L} \mathrm{NaCl}$ solution. Regarding the sample activated using the $2 \mathrm{~mol} / \mathrm{L}$, the concentration removal efficiency $(41.4 \%)$ was lower than natural mineral efficiency.

The appropriate modeling and interpretation of adsorption isotherms affect the level of data accuracy obtained in adsorption processes. The Langmuir adsorption isotherm corresponds well with the equilibrium adsorption data ( $\mathrm{R}^{2}$ ranged $0.97-0.98$ ), while the Freundlich model was found to be incompatible ( $R^{2}$ at 0.77 level).

The obtained results confirmed the observations of the research carried out by other authors. However, the solutions tested by other researchers were free of suspensions that could potentially limit the effectiveness of treatment. The suspensions in wastewater can also hinder their purification from ammonium ions by means of adsorption. For this reason, most research on this process described in the literature was carried out on synthetically prepared solutions, while our research was performed using the untreated industrial wastewater. Thus, the novel method for wastewater treatment was applied in the MBT plant.

Author Contributions: M.K. and P.S. conceived and designed the experiments; P.S. and J.P. performed the experiments; P.S., M.K., and A.U. analyzed the data; M.K. contributed reagents/materials/analysis tools; P.S., M.K., H.P.-K., and Ł.N. wrote and revised the paper.

Funding: This research received no external funding.

Acknowledgments: This research was supported by Zakład Gospodarki Odpadami GAĆ in Poland.

Conflicts of Interest: The authors declare no conflict of interest.

\section{References}

1. Du, Q.; Liu, S.; Cao, Z.; Wang, Y. Ammonium removal from aqueous solution using natural Chinese clinoptilolite. Sep. Purif. Technol. 2005, 44, 223-234. [CrossRef]

2. Taddeo, R.; Prajapati, S.; Lepisto, R. Optimizing ammonium removal by natural zeolite from wastewater with high loads of ammonium and solids. J. Porous Mater. 2017, 24, 1545-1554. [CrossRef]

3. Chen, P.; Xie, Q.; Addy, M.; Zhou, W.; Liu, Y.; Wang, Y.; Cheng, Y.; Li, K.; Ruan, R. Utilization of municipal solid and liquid wastes for bioenergy and bioproducts production. Bioresour. Technol. 2016, 215, 163-172. [CrossRef]

4. Peyravi, M.; Jahanshahi, M.; Alimoradi, M.; Ganjian, E. Old landfill leachate treatment through multistage process: Membrane adsorption bioreactor and nanofitration. Bioprocess Biosyst. Eng. 2016, 39, 1803-1816. [CrossRef] 
5. Omar, H.; Rohani, S. Treatment of landfill waste, leachate and landfill gas: A review. Front. Chem. Sci. Eng. 2015, 9, 15-32. [CrossRef]

6. Limoli, A.; Langone, M.; Andreottola, G. Ammonia removal from raw manure digestate by means of a turbulent mixing stripping process. J. Environ. Manag. 2016, 176, 1-10. [CrossRef] [PubMed]

7. Liu, L.; Pang, C.; Wu, S.; Dong, R. Optimization and evaluation of an air-recirculated stripping for ammonia removal from the anaerobic digestate of pig manure. Process Saf. Environ. Prot. 2014, 94, 350-357. [CrossRef]

8. Jorgensen, T.C.; Weatherley, L.R. Ammonia removal from wastewater by ion exchange in the presence of organic contaminants. Water Res. 2003, 37, 1723-1728. [CrossRef]

9. Rahmani, A.R.; Mahvi, A.H.; Mesdaghinia, A.R.; Nasseri, S. Investigation of ammonia removal from polluted waters by Clinoptilolite zeolite. Int. J. Environ. Sci. Technol. 2004, 1, 125-133. [CrossRef]

10. Zaghouane-Boudiaf, H.; Boutahala, M. Kinetic analysis of 2,4,5-trichlorophenol adsorption onto acid-activated montmorillonite from aqueous solution. Int. J. Miner. Process. 2011, 100, 72-78. [CrossRef]

11. Karadag, D.; Koc, Y.; Turan, M.; Armagan, B. Removal of ammonium ion from aqueous solution using natural Turkish clinoptilolite. J. Hazard Mater. 2006, 136, 604-609. [CrossRef] [PubMed]

12. Wu, Z.; An, Y.; Wang, Z.; Yang, S.; Chen, H.; Zhou, Z.; Mai, S. Study on zeolite enhanced contact-adsorption regeneration-stabilization process for nitrogen removal. J. Hazard Mater. 2008, 156, 317-326. [CrossRef] [PubMed]

13. Huang, H.; Xiao, D.; Zhang, Q.; Ding, L. Removal of ammonia from landfill leachate by struvite precipitation with the use of low-cost phosphate and magnesium sources. J. Environ. Manag. 2014, 145, 191-198. [CrossRef] [PubMed]

14. Alshameri, A.; Ibrahim, A.; Assabri, A.M.; Lei, X.; Wang, H.; Yan, C. The investigation into the ammonium removal performance of Yemeni natural zeolite: Modification, ion exchange mechanism and thermodynamics. Powder Technol. 2014, 258, 20-31. [CrossRef]

15. Huang, H.; Yang, L.; Xue, Q.; Liu, J.; Hou, L.; Ding, L. Removal of ammonium from swine wastewater by zeolite combined with chlorination for regeneration. J. Environ. Manag. 2015, 160, 333-341. [CrossRef] [PubMed]

16. Mastinu, A.; Kumar, A.; Maccarinelli, G.; Bonini, S.A.; Premoli, M.; Aria, F.; Gianocelli, A.; Memo, M. Zeolite Clinoptilolite: Therapeutic Virtues of an Ancient Mineral. Molecules 2019, 24, 1517. [CrossRef] [PubMed]

17. Alshameri, A.; Yan, C.; Al-Ani, Y.; Salman, A.; Ibrahim, A.; Zhou, C.; Wang, H. An investigation into the adsorption removal of ammonium by salt activated Chinese (Hulaodu) natural zeolite: Kinetics, isotherms and thermodynamics. J. Taiwan Inst. Chem. E 2014, 45, 554-564. [CrossRef]

18. Rockström, J.; Steffen, W.; Noone, K.; Persson, Å.; Chapin, F.S., III; Lambin, E.F.; Lenton, T.M.; Scheffer, M.; Folke, C.; Schellnhuber , H.J.; et al. A safe operating space for humanity. Nature 2009, 461, 472-475. [CrossRef]

19. Chawakitchareon, P.; Anuwattana, R.; Buates, J. Production of Slow Release Fertilizer from Waste Materials. In Advanced Materials; Parinov, I.A., Chang, S.H., Topolov, V.Y., Eds.; Springer International Publishing: Berlin/Heidelberg, Germany, 2016; pp. 129-137.

20. Leggo, P.J. The Efficacy of the Organo-Zeolitic Bio-fertilizer. Agrotechnology 2015, 4, 130. [CrossRef]

21. Huang, H.; Xiao, X.; Yan, B.; Yang, L. Ammonium removal from aqueous solutions by using natural Chinese (Chende) zeolite as adsorbent. J. Hazard Mater. 2010, 175, 247-252. [CrossRef]

22. Wang, Y.; Kmiya, Y.; Okuhara, T. Removal of low-concentration ammonia in water by ion-exchange using Na-mordenite. Water Res. 2007, 41, 269-276. [CrossRef] [PubMed]

23. Ayawei, N.; Angaye, S.S.; Wankasi, D.; Dikio, E.D. Synthesis, characterization and application of $\mathrm{Mg} / \mathrm{Al}$ layered double hydroxide for the degradation of congo red in aqueous solution. Open J. Phys. Chem. 2015, 5, 56-70. [CrossRef]

24. Ayawei, N.; Ekubo, A.T.; Wankasi, D.; Dikio, E.D. Adsorption of congo red by Ni/Al-CO $\mathrm{CO}_{3}$ Equilibrium, thermodynamic and kinetic studies. Orient. J. Chem. 2015, 31, 1307-1318. [CrossRef]

25. Brinques, G.; do Carmo Peralba, M.; Ayub, M. Optimization of probiotic and lactic acid production by Lactobacillus plantarum in submerged bioreactor systems. J. Ind. Microbiol. Biotechnol. 2010, 37, 205-212. [CrossRef] [PubMed]

26. Seruga, P.; Krzywonos, M. Screening of Medium Components and Process Parameters for Sugar Beet Molasses Vinasse Decolorization By Lactobacillus Plantarum Using Plackett-Burman Experimental Design. Pol. J. Environ. Stud. 2015, 24, 683-688. [CrossRef] 
27. Günay, A.; Arslankaya, E.; Tosun, I. Lead removal from aqueous solution by natural and pretreated clinoptilolite: Adsorption equilibrium and kinetics. J. Hazard Mater. 2007, 146, 362-371. [CrossRef] [PubMed]

28. Vázquez, I.; Rodríguez-Iglesias, J.; Marañón, E.; Castrillón, L.; Alvarez, M. Removal of residual phenols from coke wastewater by adsorption. J. Hazard. Mater. 2007, 147, 395-400. [CrossRef] [PubMed]

29. APHA; AWWA; WEF. Standard Methods for Examination of Water and Wastewater, 22nd ed.; American Public Health Association: Washington, WA, USA, 2012.

30. ANON. Handbook of Photometrical Operation Analysis; Dr Lange BDB 079; Lange GmbH: Berlin, Germany, 2000. (In German)

31. Ayawei, N.; Ebelegi, A.N.; Wankasi, D. Modelling and Interpretation of Adsorption Isotherms. J. Chem. 2017. [CrossRef]

Sample Availability: Samples of the compounds are not available from the authors.

(C) 2019 by the authors. Licensee MDPI, Basel, Switzerland. This article is an open access article distributed under the terms and conditions of the Creative Commons Attribution (CC BY) license (http://creativecommons.org/licenses/by/4.0/). 